\title{
Effect To Loving Touch Baby Massage In Increasing The Frequency Of Breastfeeding
}

\author{
Diani Octaviyanti Handajani ${ }^{1)}$, Suprapti ${ }^{2)}$, Ria Muji Rahayu ${ }^{3)}$, Endah Mulyani( ${ }^{4)}$, \\ Sulastri ${ }^{5)}$ \\ 1,2,4,5 Lecturers, Departement of Midwifery, Faculty of Health, University \\ Muhammadiyah Gresik, Indonesia \\ ${ }^{3}$ Lecturers, Departement of Midwifery, Akademi Kebidanan Wira Buana, Indonesia
}

Diani Octaviyanti Handajani. Departement of Midwifery, Faculty of Health, University Muhammadiyah Gresik. Jl. Proklamasi No.54 Trate, Gresik Regency. Email: dianiocta190@umg.ac.id Mobile: 0856-332-8-666

\begin{abstract}
Abstrak. Breastfeeding is very important in Growth and development of children both physically and mentally optimally and improve children's intelligence, and prevent children from diseases such as diarrhea, pneumonia and malnutrition which are common causes of death in children under 5 years. In breastfeeding, many factors influence, one of which is giving with loving touch baby massage. Giving with loving touch baby massage is expected to affect the frequency of breastfeeding and can increase the closeness of the child to the parents (Bonding). This research is a quasiexperimental research, namely research that aims to determine the effect that will arise after being given treatment, namely baby massage. The population in this study were 30 children under five in Domas Village, Gresik Regency. The independent variable in this study was loving touch baby massage, the dependent variable was the frequency of breastfeeding. The statistical test used was the Paired Sample T-Test. The results of this study can be concluded that there is an effect of baby massage on the frequency of breastfeeding and has a frequency of breastfeeding 7 times - 10 times / day greater than babies who are not done loving touch baby massage.
\end{abstract}

Keywords : Breastfeeding, Baby Massage

\section{Introduction}

Breastfeeding is important for health, especially for the development and survival of children, as well as preventing children from diseases such as diarrhea, pneumonia and malnutrition, which are common causes of death for children under 5 years of age [1]. The program of giving breast milk (ASI) immediately after birth and continued with exclusive breastfeeding is one way to avoid this. Breast milk (ASI) is the best food for babies at the age of 6 months of life because all nutritional needs, namely protein, carbohydrates, fats, vitamins and minerals are fulfilled in breastfeeding [2], breastfeeding can increase growth. development of the baby optimally both physically and mentally 
and improve children's intelligence. The World Health Organization (WHO) also supports breastfeeding as the best source of food to achieve optimal growth, development and health [3].

Early and exclusive breastfeeding for the first 6 months in the firsh life will help babies avoid disease. According to (SDKI) 2017, the neonatal mortality rate (IMR) is 15 deaths per 1,000 live births. Estimates show that exclusive breastfeeding can prevent infant mortality by $11.6 \%$ [4]. Research [5] also explains that babies who are not breastfed have a 3.94 times greater risk of death from diarrhea than babies who are exclusively breastfed. Research by [6] states that an estimated $85 \%$ of mothers in the world do not breastfeed optimally, only from $35 \%$ of babies who are exclusively breastfed worldwide. Even though the WHO states that the target of achieving exclusive breastfeeding in 2025 is $50 \%$, but currently, globally, only $38 \%$ of babies under the age of six months are exclusively breastfed [3]. One influence is baby massage, besides that the percentage of exclusive breastfeeding tends to fluctuate because of the many factors that influence and differences between regions [7].

Baby massage is a touch therapy to the skin using hands or what is commonly called stimulation touch [8], with touch therapy can produce beneficial physiological changes [9], touch can also stimulate stimulation in the form of verbal stimulation, visual stimulation, and auditive stimulation. The stimulation given through baby massage with a soft rub on the baby's skin surface, using the hands aims to produce an effect on the muscles, respiratory system, nerves and circulation of blood and spleen [10]. In addition, baby massage can help thegrowth and development both physically, emotionally and in defense of his health, and also affects the frequency of breastfeeding [11]. Loving touch baby massage is to massage babies with a touch of love and affection. Massage that is done with a touch of love and affection can be easy for parents to learn, by following several training it is hoped that parents can massage their own babies, and that the mother is the right person to do baby massage [12]. The touch and hug of a mother are the basic needs of the baby, which will have a tremendous impact on the development of the baby. The problem in implementing infant massage at this time is that there is still an opinion from parents or families who think that baby massage is only for therapy for babies who have flu [13]. However, the results of research by scientists and health experts show that baby massage can be done on babies who are in good health, done regularly and by providing proper baby massage techniques as well as increasing the frequency of breastfeeding.

\section{Materials And Methods}

\subsection{Materials}

This research is a quasi experimental research, which is a study that aims to determine the effect that will arise after being given treatment, namely baby massage. This research was conducted on mothers of toddlers in Domas Village, Gresik Regency from April to June 2020 with a sample size of 30 toddlers in accordance with the specified criteria.

\subsection{Experimental Design And Statistical Analysis}

Instruments used in this research are the interview sheets and the practice of baby massage, the measuring instrument used for the independent variable in this case is Loving Touch Baby Massage. The dependent variable is the frequency of breastfeeding, the statistical test used is the Paired Sample T-Test 


\section{Results And Discussion}

\subsection{Frequency Distribution Of Respondent Characteristics}

Table 1: Univariate Analysis Resulth With Descriptive Test

\begin{tabular}{lcc}
\multicolumn{1}{c}{ Variable } & n & $\mathbf{\%}$ \\
\hline Mother's age & & \\
$<35$ Years & 22 & 73,3 \\
$\geq 35$ Years & 8 & 26,7 \\
\hline Mother's Last & & \\
Education & 17 & 56,7 \\
$\quad$ S Senior High & 13 & 43,3 \\
School & & \\
$\geq$ Senior High & & \\
School & & \\
Mother's Work & & \\
Inside the house & 16 & 53,3 \\
Outside the house & 14 & 46,7 \\
\hline
\end{tabular}

Based on the data obtained from the characteristics of the research respondents, it was found that the age of the mother was mostly $<35$ years old as many as 22 people $(73.3 \%)$. Education of mothers with education < Senior High School as much as 17 people (56.7\%). and mothers work at home or not working as many as 16 people (53.3\%).

\subsection{The Effect Of Loving Touch Baby Massage On Breastfeeding Frequency}

Tabel 2 : Analysis With Paired Sample T-Test

\begin{tabular}{lcc}
\multicolumn{1}{c}{ Variable } & $\begin{array}{c}\text { Saired Samples Statistics } \\
\text { Mean }\end{array}$ & $\begin{array}{c}\text { Sig. } \\
(\mathbf{2}- \\
\text { tailed) }\end{array}$ \\
\hline $\begin{array}{l}\text { Frequency_ASI_Before } \\
\text { Massage }\end{array}$ & 7.10 & \\
$\begin{array}{l}\text { Frequency_ASI_After } \\
\text { Massage }\end{array}$ & 10.63 & .000 \\
\hline
\end{tabular}

Based on the data obtained, the results of the frequency of breastfeeding before baby massage were 7.10, and the results of the frequency of breastfeeding after baby massage were 10.63, and from the results of the statistical test analysis, the Paired Sample T-Test above indicates the sig value. $<0.05$, which means that $\mathrm{HO}$ is rejected and $\mathrm{Ha}$ is accepted, then there is an effect of baby massage on the frequency of breastfeeding and this means that babies who are given baby massage have a frequency of breastfeeding 7 times - 10 times / day greater than babies who are not done loving touch baby massage, This agrees with the research of [14] which states that most of the babies get the frequency of breastfeeding in the good category $(75.0 \%)$ with the frequency of breastfeeding approximately 8 times - 12 times / day after the baby is massaged. The frequency of good breastfeeding will increase the baby's weight, prevent the possibility of problems with growth and development problems in the baby, and besides that the frequency of breastfeeding also greatly affects the physical and emotional development of the baby [15]. 
Baby massage is a touch therapy to the skin using hands or what is commonly calledstimulation touch [8], with touch therapy performed on infant massage it can produce beneficial physiological changes [9], besides that it can affect the frequency of breastfeeding [11] so that the baby will feel comfortable and calm while breastfeeding, besides that it will cause closeness between mother and baby (bonding). Baby massage can be done alone by mothers at home, with knowledge and higher education from mothers about baby massage [16], because maternal education is high and taken is one of the factors that support a person's ability to receive information [15].

In addition, the benefits of baby massage itself, one of which is that the touch given by parents to their children will provide many positives for children, namely not only for physical development, but also giving a real effect on psychological development and development. That is why, nowadays child health experts are increasingly encouraging parents to often give touches to their children [8].

According to research conducted by Cyntia (2000) breast milk will produce more if the mother is able to massage the baby compared to mothers who do not massage the baby [17], because breastfeeding is one of the foundations of health, development and especially for the survival of the child. , as well as avoiding children from diseases such as diarrhea, pneumonia and malnutrition which are common causes of death for children under 5 years [3]. Babies who are breastfeeding hopefully will increase the baby's weight and increase the nutritional intake of the baby so that it is fulfilled. Loving touch baby massage can provide stimulation for increased activity on the vagus nerve which will increase better absorption for the digestive system. So that the baby will be hungry faster and the frequency of breastfeeding the baby will increase or often, which in the end, milk production and duration of breastfeeding will be more [15].

\section{Conclusion}

Based on the results of the study, it can be concluded that there is an effect of baby massage on the frequency of breastfeeding and has a frequency of breastfeeding 7 times - 10 times / day greater than babies who are not done loving touch baby massage

\section{References}

[1] R. N. Victora CG, Bahl R, Barros AJ, França GV, Horton S, Krasevec J, Murch S, Sankar MJ, Walker N, "Breastfeeding in the 21st century: epidemiology, mechanisms, and lifelong effect," Lancet Breastfeed. Ser. Gr., pp. 475-90, 2016, doi: 10.1016/S0140-6736(15)01024-7.

[2] K. K. Fikawati S, Syafiq A, Gizi Ibu dan Bayi. Jakarta: Pers, Raja Wali, 2015.

[3] WHO, "World Breastfeeding Week," World Health Organization, 2017. .

[4] E. M. Black RE, Victora CG, Walker SP, Bhutta ZA, Christian P, De Onis M, "Maternal and Child Nutrition 1 Maternal and Child Undernutrition and Overweight in Low-Income and Middle-Income Countries," Lancet, vol. 382-427, 2013.

[5] M. K. Ekawati S, Parlindungan DR, "Kampanye Program Pemberian ASI: Studi Deskriptif Implementasi Program Peningkatan Pemberian ASI Eksklusif di Kota Administrasi Jakarta Utara," Kalbisocio, vol. 2, 2015.

[6] G. R, Kruger .G, "Breastfeeding Practices of Mothers with Children Age 0-36 in a Rural of South Africa. A Qualitative Approach,” J. Fam. Ecol. Consum. Sci., vol. 29, pp. 60-71, 2001.

[7] P. Acharya and V. Khanal, "The effect of mother's educational status on early initiation of breastfeeding: Further analysis of three consecutive Nepal Demographic and Health Surveys Global health," BMC Public Health, vol. 15, no. 1, 2015, doi: 10.1186/s12889-015-2405-y.

[8] R. Riksani, Cara Mudah Dan Aman Pijat Bayi. Jakarta, 2012.

[9] U. Roesli, Pedoman pijat bayi. Edisi Revisi. Jakarta: Trubus Agriwidya, 2013.

[10] Y. A. Subakti, Keajaiban Pijat Bayi dan Balita. Jakarta: PT Wahyu Media, 2018.

[11] A. Falikhah, Annisa and Hidayat, "Pengaruh Pijat Bayi terhadap Frekuensi Menyusu pada Bayi Usia 0 - 3 Bulan di BPS Dini Melani Condongcatur Sleman Yogyakarta," STIKES Aisyiyah Yogyakarta, 2015. 
[12] K. S. Sutarmi, Melyana NW, Mom Massage, Baby Massage and Spa. Semarang: IHCA Institute, 2014.

[13] W. P. Rusiana AH, Tria PS, "No Title," Pengaruh loving tauch baby massage terhadap pola tidur balita, 2019.

[14] D. Purwani., "Hubungan Antara Frekuensi, Durasi Menyusui dengan Berat Badan Bayi di Poliklinik Bersalin Mariani Medan," J. Keperawatan Klin., vol. 4, no. 1, 2012.

[15] Enny. F, "Pengaruh Pijat Bayi terhadap Frekuensi dan Durasi Menyusu Bayi," J. Kesehat. Masy., vol. 10, no. 2, pp. 69-73, 2016.

[16] A. W. Cahyani WI, Rosidi A, "Gambaran Karakteristik Ibu Hamil yang Menderita Kekurangan Energi Kronis (KEK) di Kecamatan Wonosalam Kabupaten Demak,” J Kebidanan, vol. 1, no. 1, 2012.

[17] Roesli, Pedoman Pijat Bayi Prematur \& Bayi Usia 0-3 Bulan. 2011: Niaga Swadaya, 2011. 